\title{
Kemampuan Aparat Pemerintahan Kelurahan dalam Menyelenggarakan Administrasi Pemerintahan di Way Halim Permai Kecamatan Way Halim Kota Bandar Lampung
}

\section{Ability of Village Government Apparatus in Organizing Government Administration in Way Halim Permai, Way Halim District, Bandar Lampung City}

\author{
Herlintati $^{* 1}$, Henni Kusumastuti², M. Fikri Akbar ${ }^{3}$ \\ 1-3Universitas Sang Bumi Ruwa Jurai \\ Jl. Imam Bonjol No.486, Langkapura, Kota Bandar Lampung, Lampung 35118 \\ *corresponding author E-mail: herlintatisaburai@gmail.com
}

Diterima: 21 Februari; Direvisi: 29 Maret 2020; Disetujui: 31 Maret 2020

\begin{abstract}
ABSTRAK
Dengan terbentuknya Undang-Undang No. 32 Tahun 2004 tentang Pemerintahan Daerah diharapkan apa yang menjadi tujuan dan kepentingan masyarakat dapat terselenggara dengan baik. Termasuk yang bersifat pembangunan fisik maupun mental spiritual. Selain itu, dengan adanya keselarasan antara politis pemerintah maupun tujuan masyarakat juga akan menunjang terselenggaranya pembangunan kelurahan. Tujuan penelitian ini adalah untuk mengetahui kemampuan aparat pemerintahan kelurahan dalam menyelenggarakan administrasi pemerintahan kelurahan di Kelurahan Way Halim Permai Kecamatan Way Halim Kota Bandar Lampung. Metode penelitian yang digunakan dalam penelitian ini adalah metode penelitian deskritif analitis. Hasil penelitian ini menunjukkan bahwa ketiga kemampuan aparat pemerintah Kelurahan dalam menyelenggarakan administrasi pemeritahan kelurahan, ternyata ada beberapa kendala yang turut mempengaruhi kemampuan mereka, yaitu pembagian kerja yang tidak jelas pada masing-masing aparat pemerintahan kelurahan, kurangnya motivasi aparat pemerintah kelurahan dalam mejalankan tugas dan kewajibannya sebagai administrator kelurahan. Hal tersebut dikarenakan kesibukan mereka untuk mencari nafkah bagi keluarga, belum memadainya tunjangan yang diberikan oleh pemerintah kepada aparat pemerintah Kelurahan, sehingga dalam melaksanakan tugas-tugas pemerintahan Kelurahan pun belum maksimal.
\end{abstract}

Kata kunci: Administrasi Pemerintahan, Kelurahan, Kemampuan 


\begin{abstract}
With the formation of Law No. 32 of 2004 concerning Regional Government is expected to be the goals and interests of the community can be implemented properly. Including those that are physical and mental spiritual development. In addition, the alignment between government politics and community goals will also support the implementation of urban development. The purpose of this study was to determine the ability of village government officials in carrying out administrative governance in the Village of Way Halim Permai, Way Halim District, Bandar Lampung City. The research method used in this research is analytical descriptive research method. The results of this study indicate that the three capabilities of the village government officials in carrying out administrative administration of the village, in fact there are several constraints that also affect their abilities, namely the unclear division of labor in each village government apparatus, the lack of motivation of village government officials in carrying out their duties and obligations as the village administrator.That is because they are busy to make a living for the family, the insufficient allowances provided by the government to the Kelurahan government apparatus, so that in carrying out the tasks of the Kelurahan government not yet optimal.
\end{abstract}

Keywords: Ability, Government Administration, Village

\title{
PENDAHULUAN
}

Pembangunan kelurahan atau pembangunan masyarakat kelurahan merupakan bagian integral dari pembangunan nasional serta sekaligus ditujukkan pada pemerataan hasil pembangunan yang dilakukan oleh bangsa Indonesia (Sugianto, 2019). Oleh karena itu, untuk menyelenggarakan pembangunan kelurahan tersebut diperlukan seperangkat peraturan yang mengatur jalannya kegiatan pembangunan di kelurahan. Seperangkat aturan itu dimuat dalam Undang-Undang Nomor 32 tahun 2004 tentang Pemerintahan Daerah dan Peraturan Pemerintah Republik Indonesia Nomor 72 tahun 2005 tentang Kelurahan.

Dengan terbentuknya Undang-Undang tersebut diharapkan apa yang menjadi tujuan dan kepentingan masyarakat dapat terselenggara dengan baik, baik yang bersifat pembangunan fisik maupun mental spiritual. Selain itu dengan adanya keselarasan antara politis pemerintah maupun tujuan masyarakat juga akan menunjang terselenggaranya pembangunan Kelurahan (Masengi, Pangemanan, \& Kumayas, 2018). 
Sejak diberlakukan Undang-Undang Nomor 32 tahun 2004 dan Peraturan Pemerintah Republik Indonesia Nomor 72 tahun 2005 tersebut secara yuridis formal penyelenggaraan pemerintahan kelurahan secara nasional berlaku sama namun dalam hal penyebutan istilah kelurahan dapat disesuaikan dengan asal usul kondisi sosial budaya masyarakat setempat hal ini berarti pola penyelenggaraan pemerintahan dan pelaksanaan pembangunan di kelurahan harus menghormati sistem nilai yang berlaku pada masyarakat setempat, tetapi harus tetap mengindahkan sistem nilai bersama dalam kehidupan berbangsa dan bernegara. Namun pada kenyataannya apa yang diharapkan oleh Undang-Undang itu sampai sekarang belumlah berjalan secara optimal. Hal tersebut dikemukakan oleh Dirjen Pemerintahan Umum dan Otonomi Daerah (PUOD) bahwa pelaksanaan pemerintahan kelurahan belum berjalan sesuai dengan Undang-Undang Nomor 32 tahun 2004 dan Peraturan Pemerintah Republik Indonesia Nomor 72 tahun 2005 meskipun peraturan-peraturan yang menyertai UndangUndang tersebut juga diberlakukan. Adapun temuan Ditjen PUOD Depdagri tahun 2011 sebagai penghambat dalam pelaksanaan pemerintahan kelurahan tersebut adalah sebagai berikut:

1. Terdapatnya kelurahan-kelurahan yang belum memenuhi persyaratan sebagaimana ditetapkan oleh Peraturan Pemerintah Republik Indonesia Nomor 72 tahun 2005, terutama persyaratan jumlah minimal penduduk suatu wilayah.

2. Struktur Organisasi pemerintahan Kelurahan belum berfungsi sebagaimana mestinya.

3. Badan Permusyawaratan Kelurahan (BPD) sebagai lembaga permusyawaratan dan permufakatan di tingkat Kelurahan belum berjalan sesuai dengan kedudukan, tugas dan fungsinya.

4. Sulitnya mendapatkan calon-calon aparatur Kelurahan yang mampu mengelola Kelurahan dalam kedudukan sebagai administrator pemerintahan, pembangunan dan pembinaan masyarakat. 
5. Terbatasnya tingkat pendidikan dan pengetahuan aparatur pemerintah Kelurahan.

6. Belum terpenuhinya sumber pendapatan Kelurahan sesuai dengan Peraturan Pemerintah Republik Indonesia Nomor 72 tahun 2005 yaitu sebesar $10 \%$ dari anggaran perimbangan pusat dan daerah yang diterima oleh setiap Kabupaten/Kota.

7. Belum tersedianya sarana dan prasarana pemerintahan yang memadai.

8. Penyelenggaraan Administrasi yang belum tertata.

Berdasarkan gejala yang telah dipaparkan di atas mengindikasikan bahwa didalam penyelenggaraan administrasi pemerintahan Kelurahan sangat dipengaruhi oleh subjek pelaksana. Sehubungan dengan hal tersebut, Sumber Saparin (2009) mengungkapkan bahwa:

Melihat permasalahan-permasalahan di atas, maka para penyelenggara pemerintahan kelurahan dituntut memiliki adanya kemampuan serta motivasi yang tinggi, karena pada dasarnya mereka bekerja sebagai aparatur kelurahan namun tidak mendapatkan gaji yang sifatnya rutin tiap bulan diterima oleh mereka melainkan hanya sekedar pengabdian.

Bedasarkan fenomena yang terjadi di Kelurahan Way Halim Permai Kecamatan Wayhalim Kota Bandar Lampung mengindikasikan bahwa penyelenggaraan administrasi pemerintahan kelurahan belum berjalan dengan yang diharapkan. Adapun beberapa faktor ketidaktertiban administrasi pemerintahan kelurahan tersebut adalah sebagai berikut:

1. Kekurangmampuan para penyelenggara administrasi pemerintah kelurahan atau administrator kelurahan dalam penyelenggaraan administrasi pemerintahan Kelurahan.

2. Ketidakjelasan pembagian tugas pada masing-masing aparat pemerintah kelurahan.

3. Kurangnya motivasi aparat pemerintah kelurahan menjalankan tugas dan kewajibannya sebagai pelaksana administrasi pemerintahan kelurahan.

Hasil wawancara dengan Kepala Urusan (KAUR) Pemerintahan 
Kelurahan Way Halim Permai Kecamatan Wayhalim Kota Bandar Lampung serta observasi di lapangan, berkaitan dengan penyelenggaraan administrasi pemerintahan kelurahan di Kelurahan Way Halim Permai Kecamatan Way Halim Kota Bandar Lampung diperoleh hasil sebagai berikut:

1. Pelaksanaan administrasi kelurahan belum terlaksana dengan baik, terutama terjadi di Kelurahan Way Halim Permai. Dari dua belas buku panduan registrasi baru terlaksanan sekitar $60 \%$.

2. Sulitnya untuk menemukan para aparatur kelurahan yang mumpuni dikarenakan mereka lebih mengutamakan kepentingan didalam mencari nafkah untuk keluarganya, sehingga masyarakat yang mempunyai kepentingan dengan aparat kelurahan harus menunggu sampai malam hari.

3. Laporan mengenai mobilitas penduduk pada setiap bulannya dan laporan tahunan semua buku register masih sering terlambat.

4. Terjadi penumpukan beban kerja pada kepala kelurahan dan sekretaris kelurahan dalam penyelenggaraan administrasi kelurahan. Dengan demikian, jabatan kepala seksi tidak berjalan sebagaimana mestinya.

Berdasarkan uraian latar belakang di atas, penulis tertarik untuk meneliti lebih mendalam tentang kemampuan aparat pemerintahan kelurahan dalam menyelenggarakan administrasi pemerintahan di Way Halim Permai Kecamatan Way Halim Kota Bandar Lampung.

\section{METODE PENELITIAN}

Metode penelitian yang digunakan dalan penelitian ini adalah metode penelitian deskritif analitis, di mana penelitian akan ditujukan pada masalah dan fenomena yang terjadi pada masa sekarang ini. Dalam pelaksanaannya pun tidak terbatas hanya sampai pada pengumpulan data saja, tetapi data yang diperoleh dari hasil penelitian dievaluasi dan diinterpretasikan sehingga dapat ditemukan suatu kesimpulan (Sugiyono, 2013).

Dalam penelitian ini penulis merumuskan secara konseptual mengenai kemampuan aparat pemerintahan kelurahan dalam menyelenggarakan administrasi pemerintahan kelurahan, yaitu kemampuan aparat pemerintah 
kelurahan dalam menyelenggarakan administrasi pemerintahan kelurahan adalah suatu potensi, kesanggupan yang dimiliki dan dicurahkan oleh aparat pemerintahan kelurahan dalan menjalankan hak, wewenang dan kewajiban aparat pemerintahan kelurahan yang direalisasikan dalam bentuk kegiatan administrasi pemerintahan kelurahan yang meliputi bidang pemerintahan, bidang pelayanan umum dan bidang tata usaha (Yusuf, 2016). Serta dengan teknik triangulasi untuk membantu dalam penarikan kesimpulan(Bekhet \& Zauszniewski, 2012).

Untuk meningkatkan kesejahteraan masyarakat baik dalam bidang pembangunan dan pelayanan umum, kiranya dalam penyelenggaraan pemerintahan kelurahan tidak dapat terlepas dari subjek pelaksana. Oleh karena itu, pemerintah kelurahan sebagai subjek pelaksana pembangunan kelurahan dituntut memiliki kemampuan dan motivasi yang tinggi dan memadai. Salah satu bidang dalam penyelenggaraan pemerintahan kelurahan adalah bidang administrasi pemerintahan kelurahan. Administrasi pemerintahan kelurahan ini sangat penting bagi terciptanya ketertiban pelaksanaan pembangunan dan pelayanan terhadap masyarakat. Dengan melihat berbagai kondisi kelurahan yang ada di Indonesia ternyata pelaksanaan adiministrasi pemerintahan kelurahan belum berjalan dengan baik.

Berbagai masalah yang didalamnya termasuk administrasi pemerintahan kelurahan sangat memerlukan kemampuan bagi seseorang aparat pemerintah kelurahan didalam menjalankan tugasnya dan pekerjaannya, sebab kemampuan merupakan modal pokok. Karena kondisi dan latar belakang yang berbeda-beda dari masing-masing aparat, tentu saja setiap aparat memiliki kemampuan yang berbeda pula dengan aparat lainnya, baik secara fisik maupun secara non fisik. Latar belakang dan kondisi yang ada pada setiap individu tersebut akan membentuk pola kemampuan dari masingmasing aparat pemerintah kelurahan

Oleh Karena itu, untuk mengetahui bagaimana kemampuan aparat 
pemerintah kelurahan dalam menyelenggarakan administrasi pemerintah kelurahan, penulis menggunakan skala pengukuran yang dikemukakan oleh Benyamin S. Bloom dalam Della (2019), yaitu, kemampuan dilihat dari aspek kognitif, afektif, dan aspek psikomotorik. Dengan asumsi bahwa kemampuan yang optimal dari masing-masing aparat pemerintah kelurahan, maka diharapkan pelaksanaan administrasi pemerintahan kelurahan akan berjalan dengan baik, begitu juga sebaliknya.

Berdasarkan mekanisme di atas, maka dibuat dalam bagan skema penelitian yaitu:

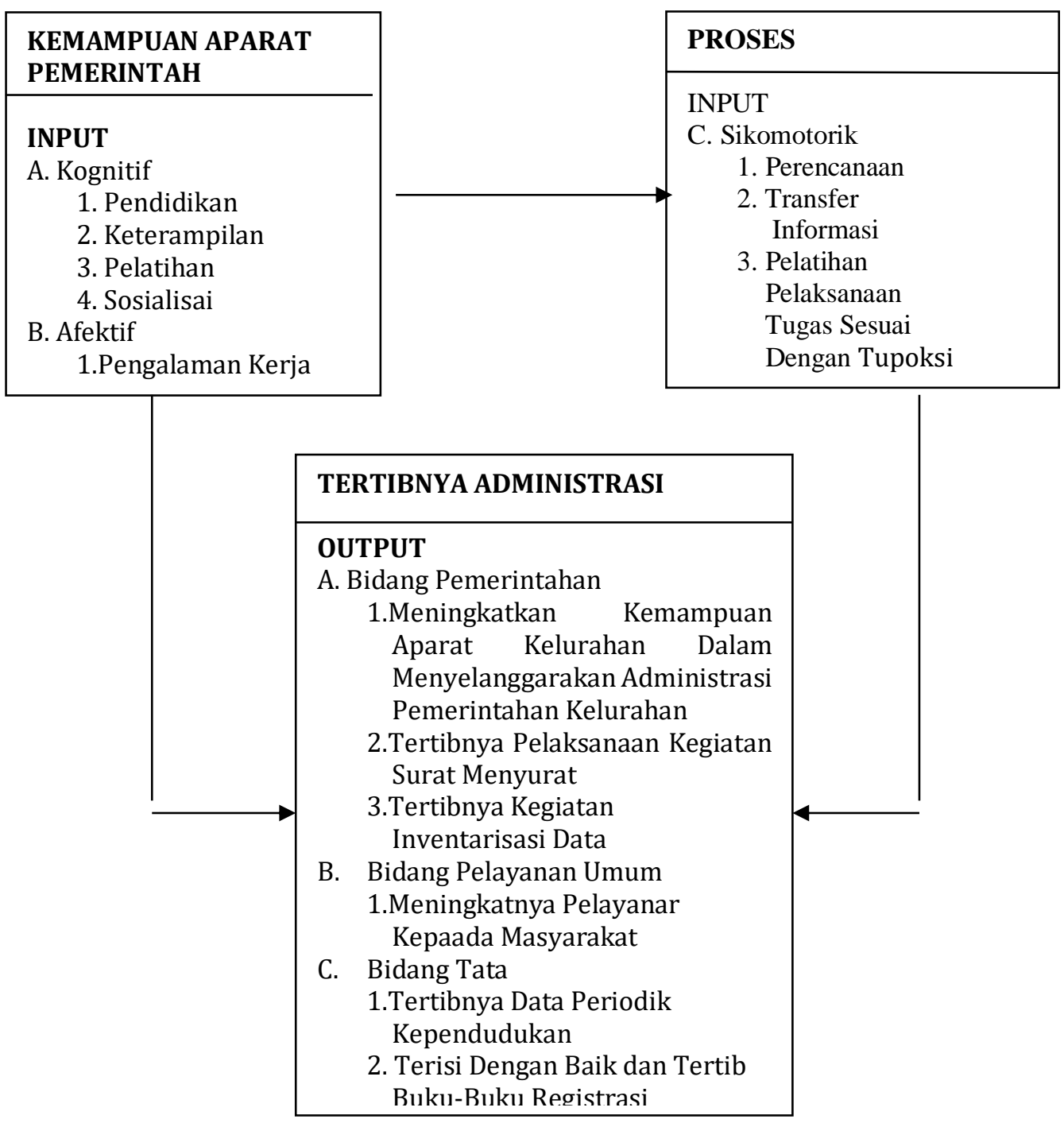

Gambar 1: Kerangka Pemikiran diolah Peneliti 2019 


\section{TEMUAN DAN PEMBAHASAN}

\section{KEMAMPUAN}

Untuk lebih jelas mengenai pengertian kemampuan akan diuraikan pengertian kemampuan menurut Kartini Kartono. Ia memberikan pengertian lain mengenai kemampuan, yaitu, segala upaya, kesanggupan, kekuatan, ketrampilan teknis dan sosial yang dianggap melebihi kemampuan anggota biasa lainnya (Kartono \& Sutrisno, 2005).

Pada batasan pertama menekankan kemampuan sebagai suatu potensi yang berhubungan erat dengan kemampuan fisik dan mental untuk melaksanakan suatu tugas atau pekerjaan. Ini menunjukkan "apa yang dapat dikerjakan" oleh seseorang dan bukan apa "ia mengerjakan pekerjaan itu". Sedangkan batasan kedua menunjukkan kemampuan sebagai suatu kesanggupan.

Untuk mengetahui klasifikasi kemampuan aparat pemerintahan kelurahan dalam menyelenggarakan administrasi pemerintahan Kelurahan, penulis akan menggunakan teori yang dikemukakan oleh Pohan (2017) berdasarkan taxonomi of education objectives (pokok-pokok pendidikan) yang diperjelas lagi dari 3 (tiga) aspek yang menjadi dasar dari semua kegiatan belajar, yaitu pengetahuan (kognitif), sikap (afektif) dan keterampilan (psikomotorik).

\section{LEMBAGA-LEMBAGA DI KELURAHAN}

Berdasarkan Undang-Undang Nomor 32 tahun 2004 tentang Pemerintahan Daerah Bab I Ketentuan Umum Pasal 1 ayat 12 dan Peraturan Pemerintah Republik Indonesia Nomor 72 tahun 2005 tentang Kelurahan Bab I Ketentuan Umum Pasal 1 ayat 5 serta Peraturan Daerah Kabupaten Lampung Barat Nomor 02 tahun 2000 tentang Penyebutan Kelurahan, Lurah dan Perangkat Kelurahan dalam Kota Bandar Lampung Bab I Ketentuan Umum yang memiliki kewenangan untuk mengatur dan mengurus kepentingan masyarakat setempat berdasarkan asal usul dan adat istiadat setempat yang diakui pemerintah nasional dan berada di daerah kota/kabupaten.

Berdasarkan Undang-Undang Nomor 32 tahun 2004 tentang 
Pemerintahan Daerah Bab I Ketentuan Umum Pasal 1 Ayat 3, Peraturan Pemerintah Republik Indonesia Nomor 72 tahun 2005 tentang Kelurahan Bab 1 Ketentuan Umum Pasal 1 Ayat 7 serta Peraturan Daerah Kota Bandar Lampung Nomor 04 tahun 2000 Bab I Ketentuan Umum Pasal 1 huruf yang dimaksud dengan kelurahan adalah kepala kelurahan dalam Kota Bandar Lampung.

Sekretaris Lurah yaitu unsur staf yang membantu lurah dalam menjalankan hak, wewenang dan kewajiban pimpinan pemerintahan Kelurahan. Berdasarkan Undang-Undang Nomor 32 tahun 2004 tentang Pemerintahan Daerah Bab XI Pasal 209 dan Peraturan Pemerintah Republik Indonesia Nomor 72 tahun 2005 tentang Kelurahan Bab I Ketentuan Umum Pasal 1 ayat 8 serta Peraturan Daerah Kabupaten Lampung Barat Nomor 03 tahun 2000 tentang Pembentukan Lembaga Himpun Pemekonan Bab 1 Ketentuan Umum Pasal 1 huruf d yang dimaksud dengan Lembaga Pemberdayaan Masyarakat yang selanjutnya disebut LPM adalah Lembaga yang terdiri dari unsur Tokoh Agama, Tokoh Adat, Tokoh Masyarakat dan Tokoh Pemuda dari masing-masing Pemangku yang berfungsi mengayomi adat istiadat, membuat peraturan kelurahan, menampung dan menyalurkan aspirasi masyarakat serta melakukan pengawasan terhadap penyelenggaraan kelurahan.

Berdasarkan Peraturan Daerah Kota Bandar Lampung Nomor 06 tahun 2000 tentang Susunan Organisasi Pemerintahan Kelurahan dan telah mengalami revisi dan diatur dengan Peraturan Daerah Kota Bandar Lampung Nomor 14 tahun 2006 tentang Organisasi Pemerintahan Kelurahan.

\section{ADMINISTRASI PEMERINTAHAN KELURAHAN}

Menurut Arsjad (2018) administrasi pemerintahan kelurahan adalah semua kegiatan atau proses yang berhubungan dengan pelaksanaan tujuan pemerintahan Kelurahan. Kegiatan atau proses yang bersumber pada wewenang hukum yang diberikan oleh keseluruhan pranata kelurahanan atau tata cara pemerintahan kelurahan dan penerapan prinsip-prinsip serta aturan 
perilaku administrasi negara oleh Badan-badan/Instansi pemerintahan agar terdapat tertib administrasi adalah kegiatan yang berhubungan dengan penyusunan organisasi, pemberian wewenang/pembagian tugas/kerja serta fungsi-fungsi pengendalian aparatur/personil, hubungan kerja, koordinasi, sinkronisasi, delegasi wewenang, dan perencanaan, pelaksanaan serta pengawasan.

Sedangkan menurut Fauzi (2019) bahwa administrasi pemerintahan kelurahan adalah segenap usaha yang perlu dilakukan oleh pemerintahan kelurahan guna memenuhi atau menjamin terlaksananya kebijakan publik yang telah ditetapkan oleh pihak atas, dan juga kegiatan dalam rangka menetapkan dan melaksanakan kebijakan penyelenggaraan urusan rumah tangga Kelurahan bersangkutan.

\section{KEMAMPUAN PENYELENGGARAAN ADMINISTRASI KELURAHAN}

Kemampuan aparat pemerintahan kelurahan dalam menyelenggarakan adminstrasi pemerintahan kelurahan adalah suatu potensi, kesanggupan yang dimiliki dan dicurahkan oleh aparat pemerintahan kelurahan dalam menjalankan hak, wewenang dan kewajiban pemerintahan kelurahan yang direalisasikan dalam bentuk kegiatan administrasi pemeritahan kelurahan. Kemampuan aparat pemerintahan kelurahan ini akan nampak jika dilihat dari aspek pengetahuan (aspek kognitif), sikap (aspek afektif) dan keterampilan (aspek psikomotorik) mereka dalam menjalankan aktifitas sehari-hari yang meliputi tugas bidang pemerintahan, pelayanan umum dan tata usaha.

Untuk kelancaran penyelenggaraan pembangunan dan roda pemerintahan kelurahan dan pelayanan terhadap masyarakat dengan baik, penyelenggaraan adiministrasi pemerintahan kelurahan tentunya mutlak diperlukan, mengingat sebagian besar penduduk Indonesia berada di wilayah Kelurahan. Tanpa ditunjang pelaksanaan administrasi pemerintahan kelurahan yang baik, tidak mungkin penyelenggaraan pembangunan, pelaksanaan pemerintahan dan pelayanan terhadap masyarakat terlaksana dengan baik. 
Ruang lingkup kerja administrasi pemerintahan kelurahan meliputi: Tugas Bidang Pemerintahan, Tugas Bidang Pelayanan Umum, dan Tugas Tata Usaha. Oleh karena itu, sesuai dengan Undang-Undang Nomor 32 tahun 2004 tentang Pemerintahan Daerah Bab 11 dan Peraturan Pemerintah Republik Indonesia Nomor 72 tahun 2005 tentang Desa, kelurahan mempunyai kewajiban untuk memnjalankan kesemuanya itu, atau dengan kata lain bahwa kelurahan berkewajiban melaksanakan tata tertib keadministrasian kelurahan.

Salah satu faktor yang menunjang dan dapat menghambat pelaksanaan administrasi pemerintahan kelurahan adalah subjek pelaksananya atau para administrator kelurahannya. Oleh karena itu, para administrator pemerintahan kelurahan dituntut untuk melaksanakan tugas dan kewajibanya itu dengan baik, salah satu aspek yang berkaitan dengan subjek pelaksana administrasi kelurahan tersebut adalah aspek kemampuan. Kemampuan disini tidak hanya fokus pada kemampuan berfikir saja, akan tetapi juga meliputi bagaimana subjek pelaksana tadi merealisasikan tugas dan kewajibannya secara nyata dan kongkrit.

\section{KEMAMPUAN KOGNITIF}

Tugas dalam bidang pemerintahan kelurahan meliputi pencatatan register yang dilakukan dalam berbagai hal ada peristiwa yang menyangkut kehidupan/tindakan warga masyarakat guna membina ketertiban warga masyarakat kelurahan dan tugas-tugas umum lain diantaranya: menerima dan melaksanakan instruksi serta petunjuk-petunjuk atasan mengenai pemerintahan, ketertiban/keamanan, tugas-tugas teknis dan kesejahteraan, membuat laporan secara periodik mengenai keadaan dan perubahan penduduk, keamanan serta sosial ekonomi wilayah kelurahan dan melaksanakan hal-hal yang sudah menjadi keputusan.

Berdasarkan hasil wawancara, maka diperoleh data bahwa responden yang menjawab ya karena alasan keterlibatannya secara langsung dalam tugas-tugas bidang pemerintahan kelurahan, dari mereka yang sudah dua kali 
menjabat sebagai aparat pemerintah kelurahan. Sedangkan dari responden yang menjawab tidak, semua diperoleh alasan bahwa selama mereka menjadi aparat pemerintah kelurahan, tidak pernah menangani masalah-masalah yang menyangkut keuangan kelurahan dan peraturan perpajakan yang ada di kelurahan, mereka yang termasuk kategori ini mereka baru pertama kali menjabat sebagai aparat pemerintah kelurahan.

Tugas bidang pelayanan umum dalam administrasi pemerintahan kelurahan adalah memberikan pelayanan kepada masyarakat kelurahan atau kepada orang lain yang membutuhkannya. Misalnya hal-hal yang menyangkut peizinan, surat keterangan tinggal, surat keterangan pindah dan surat pengantar lainnya yang berhubungan dengan keberadaan masyarakat kelurahan tersebut. Berdasarkan hasil wawancara terhadap responden yang menjawab ya, diperoleh alasan karena mereka sering terlibat langsung dalam pembuatan perizinan untuk masyarakat yang memerlukannya ataupun karena lamanya memegang jabatan sebagai aparat pemerintah kelurahan. Sedangkan responden yang menjawab tidak, semua diperoleh alasan bahwa dalam memberikan pelayanan umum aparat pemerintah kelurahan tidak mengetahui secara menyeluruh, misalnya cara pembuatan perizinan yang diminta oleh masyarakat.

Dalam bidang tata usaha, kemampuan Kognitif aparat pemerintah kelurahan difokuskan pada pengetahuan mereka mengenai penataan atau pengisian buku registrasi kelurahan dan hal-hal yang berhubungan dengan pengarsipan data kelurahan. Berdasarkan hasil wawancara, untuk responden yang menjawab ya diperoleh alasan karena mereka pernah mendapat pengetahuan mengenai penataan dan pengisian buku registrasi kelurahan dari pelatihan atau kursus yang diadakan oleh pemerintah di tingkat atas, dalam hal ini Kecamatan. Selain itu mereka terlibat langsung dalam penataan dan pengisian buku registrasi kelurahan. Sedangkan mereka yang menjawab tidak, semua diperoleh alasan bahwa selama menjadi aparat pemerintahan kelurahan tidak pernah diserahi tugas untuk mengurusi penataan atau 
pengisian buku registrasi kelurahan. Namun mereka pernah mendapat pengetahuan mengenai penataan atau pengisian buku registrasi kelurahan dari pelatihan atau kursus yang diadakan oleh pemerintah Kecamatan. Untuk mengetahui kemampuan Kognitif aparat pemerintah kelurahan dalam menyelenggarakan pemerintahan kelurahan di Kelurahan Way Halim Permai Kecamatan Way Halim Kota Bandar Lampung yang meliputi bidang pemerintahan, pelayanan umum dan tata usaha, maka dibawah ini akan dijelaskan dalam bentuk tabel.

Berdasarkan hasil wawancara, untuk mereka yang termasuk dalam kategori tinggi diperoleh alasan sebagai berikut:

1. Keterlibatannya secara langsung dalam tugas-tugas bidang pemerintahan kelurahan, dan kebanyakan dari mereka yang sudah dua kali menjabat sebagai aparat pemerintah kelurahan.

2. Keterlibatannya secara langsung dalam pembuatan perizinan untuk masyarakat yang memerlukan ataupun karena lamanya memegang jabatan sebagai aparat pemerintah kelurahan.

3. Pernah mendapat pengetahuan mengenai penataan atau pengisian buku register kelurahan dari pelatihan atau kursus yang diadakan oleh pemerintah Kecamatan. Selain itu mereka langsung terlibat dalam penataan dan pengisian buku registrasi kelurahan.

Sedangkan mereka yang termasuk dalam kategori sedang berdasarkan hasil wawancara diperoleh keterangan sebagai berikut:

1. Tidak mengetahui sepenuhnya dengan peraturan perpajakan yang menjadi wewenang pemerintah kelurahan. Pengetahuan yang mereka dapat ini dikarenakan mereka sendiri termasuk sebagai wajib pajak.

2. Terdapat aparat pemerintah kelurahan yang secara langsung tidak mengerjakan yang berkaitan dengan bidang pelayanan umum, seperti pemberian berbagai perizinan kepada masyarakat.

3. Masih ada aparat yang tidak mendapat tugas dalam penataan dan pengisian buku register kelurahan. 
Berdasarkan uraian di atas, maka dapat disimpulkan bahwa pengetahuan yang dimiliki oleh aparat pemerintah kelurahan dalam menyelenggarakan administrasi pemerintahan kelurahan di Kelurahan Way Halim Permai Kecamatan Way Halim Kota Bandar Lampung secara Kognitif termasuk kategori sedang yaitu sebesar $57 \%$.

\section{KEMAMPUAN AFEKTIF}

Kemampuan afektif aparat pemerintahan kelurahan dalam pemerintahan ini diharapkan dapat memahami dan menjelaskan hal-hal berupa: pemahaman terhadap perintah yang diberikan oleh atasannya, tentang keuangan kelurahan, aturan perpajakan, pertanahan dan pembuatan statistik kelurahan.

Berdasarkan hasil wawancara untuk mereka yang menjawab tidak, semua diperoleh alasan bahwa mereka selama menjadi aparat pemerintah kelurahan, tidak pernah menangani masalah-masalah yang menyangkut keuangan kelurahan dan peraturan-peraturan yang ada di kelurahan serta cara pembuatan statistik kelurahan. Sedangkan responden yang menjawab ya, diperoleh alasan bahwa mereka memahami secara lengkap karena terlibat langsung dalam pelaksanaan tugas-tugas tersebut. Meskipun pengetahuan mereka tetang hal tersebut cukup memadai, namun tidak dapat menjelaskan secara sempurna mengenai kedua hal tersebut.

Tugas pelayanan umum dalam administrasi kelurahan adalah memberikan pelayanan kepada masyarakat kelurahan atau kepada orang lain yang membutuhkannya. Misalnya hal-hal yang menyangkut perizinan, surat keterangan tinggal/domisili, surat keterangan berkelakuan baik serta surat keterangan lainnya yang berhubungan dengan keberadaan masyarakat kelurahan tersebut. Berdasarkan hasil wawancara untuk mereka yang menjawab tidak, semua diperoleh alasan bahwa mereka dalam memberikan pelayanan umum aparat pemerintahan kelurahan tidak dapat memahami secara menyeluruh, seperti cara pembuatan perizinan yang diminta oleh masyarakat. Sedangkan untuk mereka yang menjawab ya, diperoleh alasan 
bahwa mereka sering terlibat langsung dalam kegiatan pelayanan umum pemerintah kelurahan. Meskipun mereka pada dasarnya mengetahui mengenai perizinan, namun jika diminta untuk menjelaskan hanya sebagian saja yang dapat mereka jelaskan.

Dalam bidang tata usaha, kemampuan afektif aparat pemerintah kelurahan difokuskan kepada tingkat pemahaman mereka mengenai pengetahuan akan penataan atau pengisian buku registrasi kelurahan. Berdasarkan hasil wawancara, untuk responden yang menjawab tidak, semua dapat diperoleh alasan karena selama menjadi aparat pemerintahan kelurahan tidak pernah diserahi tugas untuk mengurusi penataan dan pengisian buku registrasi.

Sedangkan untuk mereka yang menjawab ya, diperoleh alasan bahwa mereka terlibat dalam penataan dan pengisian buku-buku registrasi kelurahan (peratin dan juru tulis) atau hanya sekedar membantu tugas peratin dan juru tulis kelurahan saja (kepala urusan). Selain itu, mereka yang mengetahui secara lengkap mengenai penataan dan pengisian buku registrasi kelurahan hanya dapat menjelaskan sebagian saja, yaitu buku registrasi yang biasanya mereka kerjakan. Sebagian responden juga ada yang beralasan bahwa mereka tidak memahami sepenuhnya data-data apa saja yang patut diarsipkan sebagai data kelurahan. Hal ini disebabkan bahwa selama ini pengarsipan data hanya dilakukan oleh peratin dan juru tulis saja. Berdasarkan uraian mengenai kemapuan afektif aparat pemerintah kelurahan dalam menyelenggarakan administrasi pemerintahan kelurahan di Kelurahan Way Halim Permai Kecamatan Way Halim Kota Bandar Lampung, secara keseluruhan dapat ditabulasikan sebagai berikut.

Berdasarkan wawancara, untuk mereka yang termasuk dalam kategori tinggi, diperoleh alasan bahwa secara umum karena keterlibatannya secara langsung dalam pelaksanaan tugas administrasi pemerintahan kelurahan. Sedangkan yang termasuk dalam kategori sedang, diperoleh alasan sebagai berikut : 
1. Para aparat pemerintahan kelurahan kurang memahami sepenuhnya terhadap peraturan perpajakan yang menjadi wewenang pemerintah kelurahan. Meskipun mereka dapat mengetahui secara jelas, namun pada prakteknya mereka tidak dapat memahami secara mandalam.

2. Terdapat aparat pemerintah kelurahan yang secara langsung tidak mengerjakan pekerjaan yang berkaitan dengan bidang pelayanan umum, seperti pemberian berbagai perizinan kepada masyrakat. Selain itu mereka tidak dilibatkan secara langsung maupun secara tidak langsung dalam pembuatan data statistik kelurahan. Jadi meskipun mereka mengetahui, tetapi mereka tidak dapat memahami apa saja data yang harus dibuat statistiknya.

3. Masih ada aparat yang tidak mendapat tugas dalam penataan dan pengisian buku-buku registrasi kelurahan, mereka juga tidak meahami jenis-jenis data apa saja yang perlu diarsipkan. Hal ini dikarenakan bahwa selama ini pengarsipan kelurahan hanya dilakukan oleh juru tulis saja.

Dari tabel tersebut di atas, maka dapat disimpulkan bahwa pengetahuan yang dimiliki oleh aparat pemerintah kelurahan dalam menyelenggarakan administrasi pemerintahan kelurahan di Kelurahan Way Halim Permai Kecamatan Way Halim Kota Bandar Lampung secara afektif termasuk dalam kategori sedang $57 \%$.

\section{KEMAMPUAN PSIKOMOTORIK}

Dalam bidang pemerintahan, kemampuan psikomotorik aparat pemerintah kelurahan diarahkan pada kemampuan secara empiris terlihat pada masalah-masalah yang berkaitan dengan bidang pemerintahan, seperti pelaksanaan tugas yang diinstruksikan oleh atasan, pembuatan laporan periodik perubahan penduduk, membuat statistik kelurahan dan hal-hal lain yang berkaitan dengan perpajakan dan pertanahan. Dalam tabel kemampuan psikomotorik ini ternyata responden yang menjawab tidak, semua/kadangkadang semakin bertambah atau membesar. Karena walaupun terdapat yang memahami mengenai pembuatan data periodik perubahan jumlah penduduk 
dan pembuatan data statistik kelurahan, ternyata secara empiris mereka tidak pernah melakukan pekerjaan tersebut.

Hal ini dikarenakan mereka tidak pernah mendapat tugas untuk membuat laporan periodik perubahan data penduduk dan statistik kelurahan. Selain itu merka juga dalam menyelesaikan persoalan yang berhubungan dengan pertanahan (agraria) banyak yang menyatakan tidak merasa mampu, karena hal itu sudah ada yang menanganinya sendiri, yaitu peratin dan juru tulis. Sedangkan mereka yang menjawab ya, dikarenakan mereka selalu mengerjakan hal tersebut dan responden yang termasuk dalam kategori ini adalah peratin, juru tulis dan kepala urusan pemerintahan.

Kemampuan psikomotorik aparat pemerintah kelurahan dalam bidang pelayanan umum penyelenggaraan administrasi pemerintahan kelurahan meliputi kemampuan aparat dalam memberikan pelayanan secara langsung kepada masyarakat kelurahan, misalnya membuat surat bukti diri, surat keterangan domisili, surat keterangan bersih diri dan membuat jenis-jenis surat yang diminta oleh masyarakat. Berdasarkan hasil wawancara, untuk mereka yang menjawab ya, diperoleh alasan mereka terlibat langsung dalam bidang pelayanan umum (Peratin dan Juru Tulis). Sedangkan untuk mereka yang menjawab tidak, semua/kadang-kadang diperoleh penjelasan bahwa mereka dalam memberikan pelayanan umum aparat pemerintahan kelurahan tidak mendapat wewenang dari atasan mereka. Misalnya cara pembuatan perizinan yang diminta oleh masyarakat, meskipun pada dasarnya mereka mengetahui, dikarenakan bukan menjadi tugasnya, maka mereka tidak berwenang untuk membuatnya. Pembuatan perizinan kepada masyarakat biasanya ditangani langsung oleh Peratin dan Juru Tulis.

Kemampuan psikomotorik dalam bidang tata usaha, diharapkan aparat pemerintah kelurahan dapat menyelesaikan hal-hal yang berhubungan dengan penataan dan pengisian buku-buku registrasi kelurahan dan mampu melakukan pengarsipan data kelurahan. Bedasarkan hasil wawancara, untuk responden yang menjawab ya, diperoleh alasan bahwa mereka sering/selalu 
mengerjakan buku registrasi kelurahan.

Sementara untuk mereka yang menjawab tidak, semua diperoleh alasan bahwa meskipun memahami cara penataan dan pengisian buku-buku registrasi kelurahan dan pengarsipan data kelurahan, namun sampai sekarang ini sedikit sekali buku-buku panduan administrasi atau buku registrasi kelurahan itu terisi. Hal ini disebabkan ada dua faktor, pertama bahwa buku registrasi kelurahan tersebut tidak dibagikan kepada semua aparat pemerintah kelurahan. Kedua, mereka tidak mempunyai waktu banyak untuk mengerjakan secara menyeluruh tugas penataan buku registrasi tersebut. Dengan begitu, meskipun mereka dapat dikatakan memahami penataan dan pengisian buku registrasi kelurahan tersebut namun dikarenakan mereka disibukkan dengan urusan mereka sendiri dalam kebutuhan sehari-hari, mereka tidak mempunyai banyak waktu untuk melakukan tugas dalam bidang tata usaha. Sedangkan untuk responden yang menjawab tidak, diperoleh alasan bahwa mereka tidak pernah melakukan penataan dan pengisian bukubuku registrasi kelurahan karena hal itu biasanya dilakukan oleh juru tulis.

Untuk melihat kemampuan psikomotorik aparat pemerintah kelurahan dalam menyelenggarakan administrasi pemerintahan kelurahan di Kelurahan Way Halim Permai Kecamatan Way Halim Kota Bandar Lampung yang meliputi bidang Pemerintahan, Pelayanan Umum dan Tata usaha, penulis akan menguraikan dan menjelaskan melalui tabel dibawah ini.

Dari ketiga bidang tugas administrasi pemerintahan pada tingkat kelurahan yang telah diuraikan sebelumnya ternyata kemampuan psikomotorik responden dipengaruhi oleh beberapa faktor sebagai berikut :

1. Terdapat responden yang selama ini menjabat sebagai aparat pemerintah Kelurahan merasa sanggup menyelesaikan masalah yang menyangkut pertanahan.

2. Tidak pernah mengerjakan tugas-tugas yang bersifat memberikan berbagai perizinan yang diperlukan oleh masyarakat.

3. Buku-buku registrasi yang ada tidak pernah dibagikan kepada mereka, dan 
mereka ada yang tidak ditugasi untuk mengisi buku registrasi tersebut.

Sedangkan hal-hal yang menyangkut pengarsipan data dilakukan oleh Juru Tulis.

Berdasarkan uraian di atas, maka dapat disimpulkan bahwa kemampuan psikomotorik aparat pemerintah kelurahan dalam menyelenggarakan administrasi pemerintahan kelurahan di Kelurahan Way Halim Permai Kecamatan Way Halim Kota Bandar Lampung dalam kategaori sedang, yaitu $57 \%$.

Dari uraian mengenai kemampuan aparat pemerintah kelurahan dalam menyelenggarakan administrasi pemerintahan kelurahan di Kelurahan Way Halim Permai Kecamatan Way Halim Kota Bandar Lampung dilihat dari kemampuan Kognitif, kemampuan afektif dan kemampuan psikomotorik terdapatnya kelemahan pada kemampuan responden mengenai masalahmasalah yang berhubungan dengan pertanahan (agraria), aturan perpajakan, pembuatan laporan periodik, pemberian perizinan kepada masyarakat, pembuatan statistik, penataan dan pengisian buku-buku registrasi kelurahan. Menurut asumsi penulis kelemahan tersebut disebabkan ada beberapa faktor yang mempengaruhi, yaitu :

1. Pembagian kerja yang tidak jelas pada masing-masing aparat pemerintah kelurahan.

2. Masih terdapatnya penumpukan tugas-tugas pada satu atau beberapa orang saja.

3. Masih rendahnya motivasi aparat kelurahan.

4. Belum memadainya tunjangan yang diberikan oleh pemerintah kepada aparat pemerintah kelurahan, sehingga dalam melaksanakan tugas-tugas pemerintah kelurahan belum dilakukan secara maksimal.

Dari uraian di atas dan gambaran tabel yang ada, dapat disimpulkan bahwa kemampuan aparat pemerintah kelurahan dalam menyelenggarakan administrasi pemerintahan kelurahan di Kelurahan Way Halim Permai Kecamatan Way Halim Kota Bandar Lampung termasuk dalam kategori 
sedang 57 \%. Kategori sedang, kemapuan aparat pemerintah kelurahan tersebut dikarenakan hal-hal sebagai berikut :

1. Bahwa aparat pemerintah kelurahan masih sulit untuk dapat membagi waktu antara tugas mereka sebagai aparat dan tugas mereka sebagai kepala keluarga.

2. Adanya motivasi dalam diri mereka untuk mengerjakan tugas dan kewajiban sebagai aparat kelurahan.

3. Adanya pembinaan, pelatihan dan sosialisasi yang dilaksanakan oleh pemerintah di atasnya dalam hal ini yaitu, pemerintah Kecamatan dan Kabupaten yang berkaitan dengan tugas aparat pemerintah kelurahan dalam bidang pemerintahan, pelayanan umum dan tata usaha.

\section{SIMPULAN}

Berdasarkan uraian mengenai kemampuan aparat pemeritah kelurahan dalam menyelenggarakan administrasi pemerintahan di Kelurahan Way Halim Permai Kecamatan Way Halim Kota Bandar Lampung pada bab-bab sebelumnya, maka penulis menyimpulkan sebagai berikut :

1. Kemampuan aparat pemerintah kelurahan dalam menyelenggarakan administrasi pemerintahan kelurahan secara kognitif termasuk dalam kategori tinggi, yaitu sebesar 63\%, termasuk di dalamnya kemampuan kognitif dalam bidang pemerintahan, bidang pelayanan umum, dan bidang tata usaha. Hal ini disebabkan karena secara umum mereka terlibat langsung dalam pelaksanaan tugas administrasi pemeritahan kelurahan, dan juga karena mereka sebagian sudah pernah mengikuti pelatihan atau kursus administrsi pemerintah kelurahan yang diselenggarakan oleh pemerintah Kecamatan.

2. Kemampuan aparat pemerintah kelurahan dalam menyelenggarakan administrasi pemeritahan kelurahan secara afektif termasuk dalam kategori tinggi yaitu 61,4\%, termasuk didalamnya kemampuan afektif dalam bidang pemerintahan, bidang pelayanan umum dan bidang tata usaha. Hal ini disebabkan karena secara umum mereka sering terlibat 
langsung dalam pelaksanaan tugas-tugas administrasi pemerintahan kelurahan.

3. Kemampuan aparat pemeritahan kelurahan dalam menyelenggarakan administrasi pemerintahan kelurahan secara psikomotorik termasuk dalam kategori sedang yaitu sebesar 57\%, termasuk didalamnya kemampuan psikomotorik dalam bidang pemerintahan, bidang pelayanan umum dan bidang tata usaha. Hal ini dikarenakan terdapatnya kelemahan pada kemampuan aparat Kelurahan mengenai masalah-masalah yang berhubungan dengan pertanahan (agraria), aturan perpajakan, dan pembuatan laporan periodik perubahan penduduk, pembuatan statistik serta penataan dan pengisian buku-buku registrasi kelurahan.

4. Secara keselurahan, kemampuan aparat pemerintah kelurahan dalam menyelenggarakan administrasi pemerintahan kelurahan di Kelurahan Way Halim Permai Kecamatan Way Halim Kota Bandar Lampung dalam kategori tinggi, yaitu 61,7\%. Hal itu dikarenakan bahwa aparat pemerintah kelurahan meskipun sulit namun dapat membagi waktu antara tugas aparat pemerintah Kelurahan dan tugas mereka sebagai kepala keluarga, motivasi dalam diri mereka untuk mengerjakan tugas dan kewajibannya dan adanya pembinaan, pelatihan dan sosialisasi yang dilaksanakan oleh pemerintah di tingkat atas dalam hal ini yaitu, pemerintah kecamatan dan kabupaten yang berkaitan dengan tugas-tugas aparat pemerintah kelurahan dalam bidang pemerintahan, pelayanan umum dan tata usaha.

\section{DAFTAR PUSTAKA}

Arsjad, M. F. (2018). Peranan Aparat Desa dalam Pelaksanaan Administrasi Pemerintahan Desa di Desa Karyamukti Kecamatan Mootilango Kabupaten Gorontalo. Gorontalo Journal of Public Administration Studies, $1(1), 16-32$.

Bekhet, A. K., \& Zauszniewski, J. A. (2012). Methodological triangulation: An approach to understanding data. Nurse Researcher, 20(2).

Della, C. T. (2019). PENGaruh Persepsi Siswa Terhadap Full Day School Pada 
POLITICON : Jurnal Ilmu Politik Vol.2 No.1; Hal.13 - 34

Website : http://journal.uinsgd.ac.id/index.php/politicon

ISSN : 2685-6670 ( Online )

Stress Akademik Siswa Sma Negeri 1 Karanganom KLATEN. Jurnal Riset Mahasiswa Bimbingan Dan Konseling, 5(7), 488-502.

Fauzi, A. (2019). Pengaruh Kompetensi terhadap Kinerja Pegawai pada Biro Pemerintahan dan Kerjasama Sekretariat Daerah Provinsi Jawa Barat. Politicon: Jurnal Ilmu Politik, 1(1), 87-101.

Kartono, \& Sutrisno. (2005). Metodologi Research. Yogyakarta: Fakultas Psikologi UGM.

Masengi, S. O., Pangemanan, S., \& Kumayas, N. (2018). Koordinasi Camat Dalam Penyelenggaraan Ketertiban Umum Di Kecamatan Tompaso Baru Kabupaten Minahasa Selatan. Jurnal EksekutiF, 1(1).

Pohan, N. (2017). Pelaksanaan Pembimbingan Belajar Aspek Kognitif, Afektif dan Psikomotorik Siswa di Madrasah Ibtidaiyah Swasta Amal Shaleh Medan. At-Tazakki: Jurnal Kajian Ilmu Pendidikan Islam Dan Humaniora, 1(2), 15-28.

Sugianto, S. (2019). Tata Kelola Anggaran Desa Bersumber APBN dalam Rangka Mewujudkan Pembangunan Masyarakat Pinggiran berbasis Pemerataan Pembangunan Pedesaan dalam Perspektif Nawa Cita (Studi Kasus di Wilayah Ciayumajakuning). Prosiding Seminar Nasional \& Call for Papers Hukum dan Industri.

Sugiyono. (2013). Metode Penelitian Pendidikan Pendekatan Kauntitatif, kualitatif dan R\&D. Bandung: Alfabeta.

Sumber, S. (2009). Administrasi Pemerintahan Desa dan Kelurahan. Jakarta: Ghalia Indonesia.

Yusuf, A. M. (2016). Metode penelitian kuantitatif, kualitatif \& penelitian gabungan. Prenada Media. 